\title{
The Māori statistics framework: A tool for indigenous peoples development
}

\author{
Karen Coutts*, John Morris and Ngareta Jones \\ Māori Advice Team, Statistics New Zealand, New Zealand
}

\begin{abstract}
The Māori Statistics Framework (MSF) is a tool developed by Statistics New Zealand. This tool is known as He Arotahi Tatauranga. While it is a general resource for those working in the area of statistics for and about New Zealand's indigenous population (Māori) it is intended to be to be used primarily by Māori to organise and use their information in a way that supports their development and well-being consistent with their aspirations as a people.

The MSF has been derived from a conceptual paper that the project team then used to create a unique tool. Because the aims and concepts of the MSF come from the Māori view of well-being it can be used to define statistics from this viewpoint. The MSF also helps users understand the difference between traditional statistics that measure Māori from a standard approach and how to measure from a Māori perspective.

The MSF tool is an Excel spreadsheet with accompanying guidance and supplementary information in attached Word documents. The users of the MSF are guided in a transparent manner through:

- How they can build their own information management system from a Māori perspective

- How to think statistically about the concepts and topics relevant to Māori development from a Māori viewpoint

- How to identify what type of measurement(s) would suit the user

- Whether or not an indicator already exists that could be used for such measurement.
\end{abstract}

Keywords: Māori, Māori statistics framework, Māori development and well-being, Statistics New Zealand

\section{Introduction}

Māori are the indigenous population of New Zealand. Around 1 in 7 (690,300 or 14.9 percent) New Zealanders are Māori (2013 Census), a 5.9 percent increase from 2006 Census.

Māori historically lived in tribal structures which are still important today. Many now live outside traditional tribal areas but still maintain language, genealogical, tribal, and cultural behaviours whilst living in urban areas or outside New Zealand.

Similar to many other indigenous populations, Māori have suffered during the colonisation period of New Zealand, and continue to show disadvantage in many areas. However, through pressures from Māori

*Corresponding author: Karen Coutts, Māori Advice Team, Statistics New Zealand, New Zealand. E-mail: info@stats.govt.nz. that have spurred Māori renaissance through the $20^{\text {th }}$ century, there are emerging positive changes occurring for Māori. The Waitangi Tribunal, established in 1975, has allowed the Crown (government) to settle historical grievances with many Māori institutions, such as tribal groups (iwi). For iwi, this has resulted in the redistribution of assets back to them, which has spurred growth in the Māori economy and increased focus of Māori and non-Māori on Māori development to achieve aspirations of well-being as determined by Māori.

The Treaty of Waitangi, signed in 1840 between Māori and the British Crown, created a constitutional basis for New Zealand and defined the relationship between Māori and the Crown (Government of New Zealand). All government departments are obliged to take into account Treaty of Waitangi obligations and meeting their responsibilities to Māori as part of their work. 
Statistics New Zealand (Statistics NZ) is the national statistics office for New Zealand and is responsible for gathering and publishing official statistics about New Zealand.

Information is vital to the relationship between Māori and the Government of New Zealand. The need for information by both Māori and the New Zealand Government to make informed decisions has become central to this relationship. Building on previous work, Statistics NZ has developed the MSF to guide producers and users of this information.

The MSF tool is an Excel spreadsheet with accompanying guidance and supplementary information in attached Word documents. The users of the MSF are guided in a transparent manner through:

- How they can build their own information management system from a Māori perspective

- How to think statistically about the concepts and topics relevant to Māori development from a Māori viewpoint

- How to identify what type of measurement(s) would suit the user

- Whether or not an indicator already exists that could be used for such measurement.

The MSF is a critical tool in the range of ways Statistics NZ will fulfil its Treaty of Waitangi obligations and responsibilities to Māori as a government department. The MSF can be accessed from the Statistics NZ website as He Arotahi Tatauranga [1].

Appendix 1 to this paper provides more detailed information about the history of Māori in New Zealand.

\section{Purpose of the MSF}

Māori need good quality statistical information to inform their own debates, decision-making, and research, and to assist them to monitor the effects of government policies and programmes relating to Māori. Official statistics produced by Statistics NZ and the broader Official Statistics System (OSS) go some but not all of the way toward meeting these needs.

Statistics NZ has been aware of and concerned by the limited relevance of much of the official data on Māori issues for some time now. The MSF is Statistics NZ's attempt to provide a framework and methodology for viewing and producing statistics about Māori development and Māori well-being from a Māori perspective.

The purpose of the MSF is to guide those who use and produce Māori statistics in various ways including:
- Statistics NZ and the OSS can use the MSF as a guide to meeting the information needs of Māori.

- Researchers will know what data about and for Māori is available and ways to bring this data together.

- Māori entities can use the MSF to organise their information, standardise this information so it can be aggregated or compared with national data, and prioritise the information they wish to collect and store.

The main benefits of the MSF are:

- Supporting Statistics NZ, and other OSS agencies, to meet strategic priorities and commitments to Māori by:

* Improving the relevance of the statistics collected for use by Māori to inform them about their overall well-being status and to support policy and planning decisions, and

* Guiding the process of prioritisation of statistical information for and about Māori.

- Providing a tool to allow discussion of Māori statistics to occur from a common point of reference.

- Providing guidance on the standardisation of concepts, terms, methodologies to allow consistent collection of data over time from different sources, and meaningful comparison across regions, different sub populations and internationally.

- Providing linkages between measures looking at different conceptual views of an issue.

\section{Māori involvement in the development of the MSF}

The basis for the MSF was the 2002 draft Māori Statistics Framework [2]. The development of the draft Māori Statistical Framework was initiated and had input from the Māori Statistics Forum. The Māori Statistics Forum was a group of eminent Māori academics tasked with providing advice to the New Zealand Government Statistician.

The further development of the MSF following publication of the 2002 paper received feedback from the Māori Statistics Advisory Committee (MSAC). The MSAC was the successor to the Māori Statistics Forum. Other prominent Māori academics and users of statistics also provided feedback. The MSF is seen as a living document and feedback is invited from users to further develop it. 


\section{Statistics for and about Māori}

Under-pinning the MSF is the concept of statistics for Māori as opposed to statistics about Māori. What do we mean by these terms?

Traditionally, Māori have appeared in statistical publications as a separate ethnic group within the wider population, and this has meant a focus on how Māori compare with other ethnic groups and the total population. Hence we have statistics on the Māori unemployment rate, the Māori crime rate, the median income of Māori, etc. These are what could be called Statistics about Māori in that they define Māori by their similarity or difference, i.e. their comparative development, from the population in general. These have validity in some cases and have a role in understanding New Zealand and making informed decisions. However, these statistics do not measure what being Māori means, nor are they as pertinent to decision-making in relation to Māori development to meet Māori aspirations as determined by Māori.

Statistics for Māori are statistics that contribute measures of Māori well-being from Māori perspectives. They focus on how Māori value the world, the activities that Māori do and what makes them unique. As the 2002 draft Māori Statistics Framework states "It does not attempt to define what the 'good life' is but instead takes a pluralistic approach. It is, therefore, at odds with the use of comparisons to measure Māori development."

Typically statistics for Māori would also encompass subsets meaningful to Māori such as iwi, hapū (kinship groups; sub-tribe) and whānau (extended family group) and geographic breakdowns that include rohe (territory). An example of a statistic for Māori using this description would be number of Māori language speakers by iwi, by rohe.

Figure 1 statistics 'about' and 'for' Māori shows how Statistics NZ conceptualises the types of information that are needed to meet information needs in a Crown-Māori relationship. Both types of information are needed and may be produced by either the Crown or Māori. Where the Crown and Māori need to exercise decision-making together over a common resource or issue (such as the preservation of Māori language) is where it is a priority to have both types of information available so a fully informed decision is based upon all perspectives.

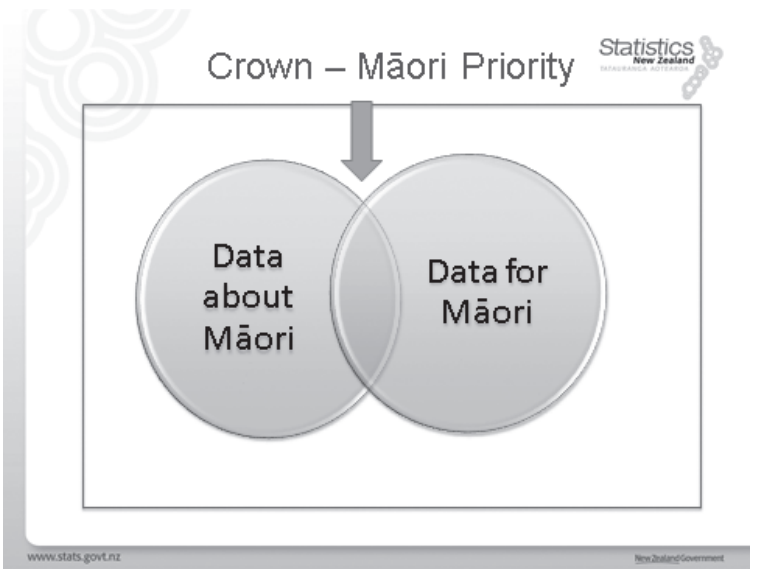

Fig. 1. Statistics 'about' and 'for' māori.

\section{Structure of MSF}

The MSF is a statistical approach to measuring Māori well-being and development in the areas of most interest to Māori.

The concept of Māori well-being is aspirational and for purposes of measurement, needs to be clarified by unpacking its various dimensions. It is important for the user of the MSF to understand that the process of identifying the dimensions of a concept involves the exercise of value judgement and that one of the most important functions of a statistical framework is to make those judgements transparent.

In making its choices, Statistics NZ was guided by the theoretical perspectives referenced and the literature on Māori development including the Māori Development Narrative developed by Statistics NZ [3].

In the MSF, Māori well-being is made up of six dimensions.

\subsection{Te ao Māori}

Te ao Māori denotes the Māori world. This dimension refers to key areas such as te reo Māori (Māori language and dialects) tikanga Māori (protocols and customs) and mātauranga Māori (way of building knowledge and skills), which help to define what it means to be Māori and the cultural diversity within Māoridom.

\subsection{Human resource potential}

Human resource potential from a Māori view is articulated by mātauranga Māori, which encompasses education, knowledge, wisdom, understanding, and skill. It also covers areas of Māori population char- 
acteristics (such as health) and the talents (productive wealth) embodied within the population's labour, skills, and knowledge and the potential to achieving desired states or activities.

\subsection{Empowerment and enablement}

Empowerment and enablement recognises individual and group capability of achieving desired states or activities. It includes concepts such as 'whakamana' which acknowledges that the capability and opportunity for Māori to make decisions, to act in selfdetermining ways, and to actively influence decisions that affect their lives, is integral to individual and collective well-being.

\subsection{Economic self-determination}

Economic self-determination is captured in tino rangatiratanga, which reflects that Māori retain rangatiratanga over their resources and taonga but not at the expense of having all the rights and privileges of citizenship. Economic self-determination recognises the desire of people to determine their own destiny relating to economic well-being in having the material wealth and income to meet their own needs and to contribute to the wider economic growth.

\subsection{Social capability}

Social capability is expressed in the concept of mauri, the life principle. It covers aspects such as the ability, skill and talent to interact and coordinate with other people and groups to realise goals. It includes related concepts such as social capital and social cohesion.

\subsection{Environmental sustainability}

Environmental sustainability is seen in te ao Māori as kaitiakitanga meaning guardianship and protection. This dimension recognises the importance of the natural environment and how it provides resources for economic development and meaning and context for social and cultural development. Sustainability also acknowledges the importance of ensuring that what is utilised is done so in a way that coming generations can also utilise the same things to the same degree.

The interactions between the dimensions are a key part of the framework. Each of the dimensions is of equal importance and in the long run no dimension can be achieved at the expense of any other. This ensures all aspects of life contributing to Māori wellbeing are included according to their own values and preferences.

\section{Māori development topics}

Within the six dimensions, there are 18 topics that are areas of significant interest to Māori development. Topics ${ }^{1}$ also correspond to important aspects of quality of life or well-being.

The topics are:

$\begin{array}{lll}\text { - Māori language } & \text { - Population } & \text { - Housing } \\ \text { - Māori knowledge } & \text { - Families and } & \text { - Income and } \\ \text { - Marae } & \text { households } & \text { expenditure } \\ \text { - Wāhi taonga } & \text { - Social connections } & \text { - Work } \\ \text { - Wāhi tapu } & \text { and attachments } & \text { - Social issues } \\ \text { - Māori land } & \text { - Modern knowledge } & \text { - Māori business } \\ & \text { - Skills and } & \text { development } \\ & \text { competencies } & \text { - Participation in } \\ & \text { - Health } & \text { political decision- } \\ & & \text { making processes } \\ & & \text { - Rights }\end{array}$

If we are interested in Māori well-being and Māori development then the MSF as a tool must help determine the range of things we want to know about these two concepts, how to think about these things quantitatively, and the choices of measurements that may exist.

The framework is intended to measure dimensions of Māori well-being and hence the progress of Māori development in the context of the topics of interest to Māori.

Each Māori development topic intersects with one or more of the Māori well-being dimensions. Appendix 2 shows the matrix of intersections between the dimensions and topics to provide a rationale as to why the intersections are of interest and relevant to Māori wellbeing and Māori development. Combined, the dimensions and topics provide a way for users to determine measures for which indicators they wish to use in their decision-making.

\section{Using the MSF - the MSF spreadsheet}

The MSF spreadsheet presents the MSF as a tool. The spreadsheet allows the user to look at the definition for each dimension and topic and also the rationale and questions relevant for each intersection. From these questions users can link to some of the measures

\footnotetext{
${ }^{1}$ Topics correspond to important aspects of the quality of life or well-being. In the 2002 consultation paper these were called 'areas of interest' - this has since been changed to topics. Topics better relate to the terminology used in domain plans produced by Statistics New Zealand.
} 
we need to answer these questions, then to the current indicators we have for these measures, and finally to the source of the indicators. The current gaps we have in indicators should be readily identified as areas where we have no indicators for the measures we require.

Figure 2 shows the process of moving through the framework to determine appropriate indicators to provide insight into areas of significant interest to the user or community and to provide answers to pertinent questions. These questions may be prompted by the matrix of the MSF (Appendix 2) as it highlights the range of possible measures covered by the MSF.

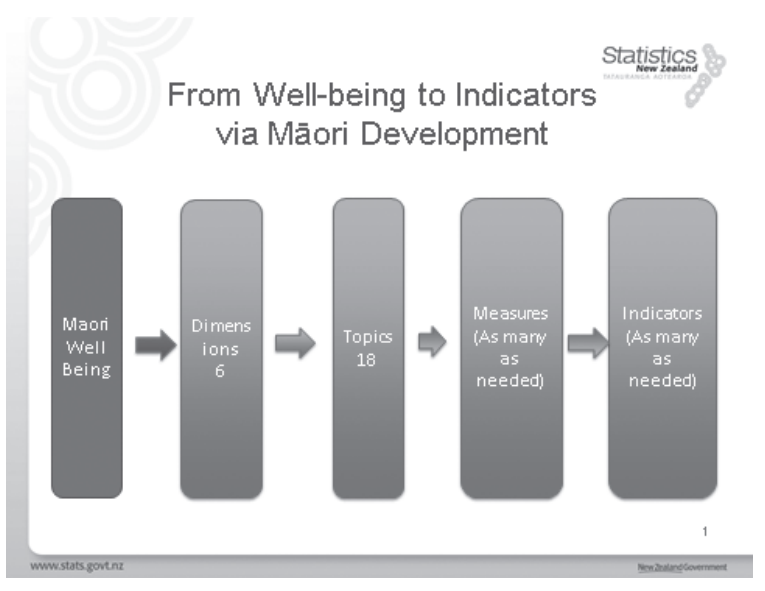

Fig. 2. From Māori well-being to indicators via Māori development.

Users can also use the spreadsheet to go across topics and down dimensions as they wish. Users are encouraged to experiment with the framework.

\section{Conclusion}

The MSF has been developed to be used by a wide range of users groups. However, as it is a measure of Māori well-being via Māori development it will be of greater assistance and use to Māori.

We particularly encourage Māori stakeholders, users, and producers to use the framework to support their individual or group development. For example, an iwi may take the framework and use it to source data to determine the state of well-being and development of their iwi. There may be information gaps in the measures suggested by the framework that can only be populated by iwi.

Statistics NZ will also use the MSF to help guide discussions with partners in the OSS and Māori producers on the priority statistics that are needed for
Crown-Māori joint decision-making, and where production best lies. It takes us into new areas of measurement and also new ways to consider meeting our obligations. Of importance, the MSF will challenge who is best placed to be producer - Statistics NZ or Māori - and the priority of supporting capability building if Māori are to become partners in production of official statistics.

\section{References}

[1] Statistics New Zealand (2014) He Arotahi Tatauranga. Available from www.stats.govt.nz.

[2] Statistics New Zealand (2002). Towards a Māori Statistics Framework: A discussion document. Available from www. stats.govt.nz.

[3] Statistics New Zealand (2012), Māori Development Narrative A Resource for Statistics New Zealand staff (unpublished), Statistics New Zealand, Wellington.

\section{Appendix 1 - The Māori people of Aotearoa (New Zealand $)^{2}$}

Origins

The Māori people of Aotearoa (New Zealand) are descendants of Polynesian peoples who had arrived in New Zealand by canoe around 1300 AD. Most canoes explored the coasts, reconnoitring the land and seeking safe haven. Māori oral tradition indicates that by the end of the 14th century the entire country had been explored, although Māori remained close to their initial settlements. These early settlements were often at harbours or the mouths of rivers - close to the sea, with good access to fishing and shellfish grounds. Increasingly Māori developed horticulture. With careful techniques, they succeeded in establishing several plants, especially the kūmara (sweet potato). They also turned inland, and over several generations Māori culture moved from being largely maritime to one which, in certain places, was dominated by trees and bird life.

Pre-European, Māori culture was oral, and based on small autonomous sub-tribes (hapū) living in valleys, harbours and other localities. The values of the society arose from its communal nature. Individuals were seen as the repository or the voice of the group. There

\footnotetext{
${ }^{2}$ Te Ahukaramū Charles Royal. 'Māori', Te Ara - the Encyclopedia of New Zealand, updated 30-Apr-14 URL: http://www.TeAra. govt.nz/en/maori/sources.
} 
was a tapestry of intricate genealogical relationships (whakapapa), and the notion that what affects a part also affects the whole was strongly upheld. Similarly there was a belief that humans were part of nature - the forests, seas and waterways. People saw themselves in a sacred relationship with the natural world, and the exploitation of natural resources was conducted under strict regimes of tapu (sacredness) and mana (spiritual authority) administered by tohunga (priests).

By the time of European arrival, Māori had settled the land, and every corner came within the interest and influence of a particular tribal (iwi) or sub-tribal (hapū) grouping.

The period from approximately 1800, when Europeans began to settle, to the signing of the Treaty of Waitangi in 1840, is distinguished by major upheaval in the Māori world. This was the period of the wars between antagonistic tribes (iwi) and Christian missionary work began to affect Māori.

\section{The Treaty of Waitangi}

In 1840, a treaty was signed by representatives of Queen Victoria of England and more than 500 Māori chiefs representing numerous tribes throughout the country. The effect of the Treaty of Waitangi was to bring intertribal conflict to an end, and to provide a constitutional basis for the establishment of British law and government in New Zealand. The English version of the treaty stated that sovereignty was ceded to the Queen of England. However, the Māori version said that the treaty guaranteed 'tino rangatiratanga' or chieftainship of New Zealand to Māori. The debate continues today.

\section{After the Treaty of Waitangi}

The period between 1840 and 1860 saw the rise of a new economy within tribal (iwi) societies. Many tribes took to growing crops and selling their produce to markets such as the new towns of Auckland and Wellington. Some even traded with markets in Australia.

However, in both the north of the South Island and the far north of the North Island, the mid-1840s saw violence break out between Māori and Pākehā (colonialists) as Māori sought to hold on to their land and local authority. In the 1860 s, the conflict became more severe as Pākehā settlers, mostly British, hoped to gain land for a growing population. While at times Māori exhibited a remarkable inventiveness and tenacity in the wars, they eventually lost millions of acres of land.
This was partly the result of confiscation, and partly the influence of new government institutions such as the Native Land Court. This was set up to facilitate the sale of land by transferring land titles from tribes and putting them into individual names.

During the early years of the 20th century, Māori society and culture reached its lowest ebb. Introduced diseases had helped reduce the estimated numbers of Māori to under 50,000 - the lowest ever - in a total population of over 800,000 . With a smaller population and dwindling resources, Māori influence upon the affairs of the nation was drastically reduced.

The period between 1900 and 1950 is dominated by the work of Sir Apirana Ngata and other important Māori leaders of the $20^{\text {th }}$ century. Their numerous initiatives and enterprises included:

- Entry into Parliament (and at times membership of the Cabinet)

- The formation of the Pioneer and Māori Battalions who saw action in both world wars

- The introduction of widespread health reforms under Buck and Pōmare

- The reform of land tenure arrangements.

Following the Second World War, many Māori elected to move from their tribal and rural communities to find work in the bigger centres. While some Māori attempted to bring traditional institutions into the cities - by establishing urban marae for example, urbanisation brought major change to the Māori world. Older tribal structures lost influence, and urban-based Māori became educated in western institutions.

During the late 1960s there was a growing awareness of the impact of colonisation on Māori, and urban Māori protest movements such as Ngā Tamatoa (the young warriors) emerged. This and other groups of mainly urban Māori spearheaded protest, in the 1970s, about loss of land and culture. In 1975, led by Dame Whina Cooper, thousands of Māori from all over the country walked the length of the North Island, from Te Hāpua down to the nation's capital, Wellington. In a powerful and innovative way the land march embodied Māori protest over ongoing land alienation. Political activism continued at Waitangi, and in 1977-78 the Ngāti Whātua people occupied Bastion Point above Ōkahu Bay in Auckland. The tribe had been evicted from the bay in 1951, after continuing alienation of their land by the Crown from 1870 .

The Waitangi Tribunal, designed to address perceived breaches of the Treaty of Waitangi, was established in 1975. The tribunal became a forum for the expression of much Māori protest and anger over the 
impact of European colonisation. Its findings have led to settlements with tribes which have returned some assets to tribes.

\section{Renaissance}

There has been a significant renaissance in the state of Māori culture, economy and society during and since the 1970s. Major claims regarding the historical dispossession of tribal estates have been brought before the Waitangi Tribunal; the management of tribal or Māori-owned assets has been rearranged; a Māorilanguage education system has been established; and Māori have started major industry initiatives including fishing, aquaculture and farming.

There is now a wide range of Māori-owned enterprises such as television and radio, businesses and tourist ventures. Additionally, there is significant political representation, and an increasing number of individuals are gaining international reputations for their achievements. Today, Māori people can be found in a wide array of pursuits and activities throughout the country and the world.

\section{Language}

The Māori language is an official language of New
Zealand, and in recent years has undergone a revival. However, it is still considered threatened and, according to the 2013 Census, 125,352 Māori (21.3 percent) could hold a conversation about a lot of everyday things in te reo Māori. This is a 4.8 percent decrease from the 2006 Census.

\section{Culture}

Māori culture is going through enormous change, with the establishment of new institutions and organisations. These include:

- The creation of Māori educational institutions where teaching and learning is conducted substantially in the Māori language. In 2001 there were over 500 kōhanga reo (language nests), teaching over 10,000 preschool children; over 50 kura kaupapa Māori (teaching schoolchildren in full Māori-language immersion programmes); and three whare wānanga (tertiary institutes)

- The rearrangement and strengthening of tribal structures and councils

- The recapitalisation of tribally owned assets

- The establishment of over 20 Māori radio stations and a television channel

- Māori political representation, with 16 MPs of Māori background in Parliament in 2004. 
Appendix 2 - Matrix of Māori well-being dimensions and Māori development topics

\begin{tabular}{|c|c|c|c|c|c|c|}
\hline \multirow[b]{2}{*}{ Topics } & \multicolumn{6}{|c|}{ Dimensions } \\
\hline & Te ao Māori & Human resource potential & Empowerment and enablement & Economic self determination & $\begin{array}{l}\text { Social capability } \\
\end{array}$ & Environmental sustainability \\
\hline Māori language & $\begin{array}{l}\text { Māori language is an intrinsic } \\
\text { part of being Māori }\end{array}$ & $\begin{array}{l}\text { Human resource potential for } \\
\text { using Māori language }\end{array}$ & $\begin{array}{l}\text { Acknowledging Māori } \\
\text { language as official language }\end{array}$ & $\begin{array}{l}\text { Economic value/use of Māori } \\
\text { language }\end{array}$ & $\begin{array}{l}\text { Māori language is important } \\
\text { for measuring social connec- } \\
\text { tions among Māori }\end{array}$ & \\
\hline Māori knowledge & $\begin{array}{l}\text { Māori knowledge is an intrinsic } \\
\text { part of being Māori }\end{array}$ & $\begin{array}{l}\text { Human resource potential for } \\
\text { using Māori knowledge }\end{array}$ & $\begin{array}{l}\text { Recognition of tino rangitira- } \\
\text { tanga under the Treaty of } \\
\text { Waitangi }\end{array}$ & $\begin{array}{l}\text { Traditional Māori knowledge } \\
\text { applied to economic develop- } \\
\text { ment (eg traditional medicines) }\end{array}$ & $\begin{array}{l}\text { Māori knowledge defines so- } \\
\text { cial interaction between Māori }\end{array}$ & $\begin{array}{l}\text { Māori knowledge covers } \\
\text { preservation of resources for } \\
\text { current and future generations }\end{array}$ \\
\hline Marae & $\begin{array}{l}\text { Marae is a defining characteris- } \\
\text { tic of what it means to be Māori }\end{array}$ & $\begin{array}{l}\text { Marae is a place to develop hu- } \\
\text { man resource potential }\end{array}$ & $\begin{array}{l}\text { Use of marae in decision mak- } \\
\text { ing }\end{array}$ & $\begin{array}{l}\text { Use of marae for economic de- } \\
\text { velopment }\end{array}$ & $\begin{array}{l}\text { Marae play an important role in } \\
\text { Māori social capability }\end{array}$ & \\
\hline Wāhi taonga & $\begin{array}{l}\text { Wāhi taonga are places valued } \\
\text { by Māori }\end{array}$ & $\begin{array}{l}\text { Understanding wāhi taonga } \\
\text { concepts }\end{array}$ & Control and use of wāhi taonga & $\begin{array}{l}\text { Economic value placed on wāhi } \\
\text { taonga }\end{array}$ & $\begin{array}{l}\text { Wider societal connections } \\
\text { around wāhi taonga }\end{array}$ & $\begin{array}{l}\text { Wāhi taonga need to be sus- } \\
\text { tained for future generations }\end{array}$ \\
\hline Wāhi tapu & $\begin{array}{l}\text { Wāhi tapu are sites that have } \\
\text { significance in what is means to } \\
\text { be Māori }\end{array}$ & $\begin{array}{l}\text { Understanding of concepts of } \\
\text { whahi tapu }\end{array}$ & Control and use of wāhi tapu & $\begin{array}{l}\text { Economic value placed on } \\
\text { wāhi tapu }\end{array}$ & $\begin{array}{l}\text { Wider societal connections } \\
\text { around wāhi tapu }\end{array}$ & $\begin{array}{l}\text { Wāhi tapu need to be sustained } \\
\text { for future generations }\end{array}$ \\
\hline Māori land & $\begin{array}{l}\text { Land and access/control of it } \\
\text { are of importance in defining } \\
\text { what it means to be Māori }\end{array}$ & & $\begin{array}{l}\text { Rights of access and use of } \\
\text { Māori land }\end{array}$ & $\begin{array}{l}\text { Ownership and control of } \\
\text { Māori land is a means of Māori } \\
\text { economic development }\end{array}$ & $\begin{array}{l}\text { Social connections through col- } \\
\text { lective ownership of land }\end{array}$ & $\begin{array}{l}\text { Māori land needs to sustained } \\
\text { for future generations }\end{array}$ \\
\hline Population & $\begin{array}{l}\text { Those who consider them- } \\
\text { selves as Māori define the } \\
\text { Māori people }\end{array}$ & $\begin{array}{l}\text { Those who consider them- } \\
\text { selves Māori contain the } \\
\text { human resource potential for } \\
\text { Māori }\end{array}$ & $\begin{array}{l}\text { The enablement and empower- } \\
\text { ment of populations is impor- } \\
\text { tant }\end{array}$ & $\begin{array}{l}\text { Economic self-determination } \\
\text { of the Māori population } \\
\text { collectively }\end{array}$ & $\begin{array}{l}\text { Social interactions of those } \\
\text { who consider themselves } \\
\text { Māori }\end{array}$ & $\begin{array}{l}\text { Māori population impact on the } \\
\text { environment }\end{array}$ \\
\hline $\begin{array}{l}\text { Families and } \\
\text { households }\end{array}$ & $\begin{array}{l}\text { Te ao Māori places great value } \\
\text { on families (whānau) and de- } \\
\text { scent (whakapapa) }\end{array}$ & $\begin{array}{l}\text { Human resource potential of } \\
\text { households containing Māori }\end{array}$ & $\begin{array}{l}\text { Decision-making within } \\
\text { whānau }\end{array}$ & $\begin{array}{l}\text { Māori families contribution to } \\
\text { economic development }\end{array}$ & $\begin{array}{l}\text { Families containing Māori in- } \\
\text { teractions with society }\end{array}$ & \\
\hline $\begin{array}{l}\text { Social connectedness } \\
\& \text { attachments }\end{array}$ & $\begin{array}{l}\text { Te ao Māori is a way of defin- } \\
\text { ing societies within NZ and the } \\
\text { linkages between them }\end{array}$ & $\begin{array}{l}\text { Contribution of social interac- } \\
\text { tions to developing human re- } \\
\text { source potential }\end{array}$ & $\begin{array}{l}\text { Use of social connections to } \\
\text { achieve outcomes and make de- } \\
\text { cisions }\end{array}$ & $\begin{array}{l}\text { Use of social connections for } \\
\text { economic development }\end{array}$ & $\begin{array}{l}\text { Social connections and attach- } \\
\text { ments are a means of fostering } \\
\text { social capability }\end{array}$ & \\
\hline $\begin{array}{l}\text { Modern knowledge, } \\
\text { skills, \& competen- } \\
\text { cies }\end{array}$ & $\begin{array}{l}\text { Te ao Māori interacts and } \\
\text { changes with modern knowl- } \\
\text { edge }\end{array}$ & $\begin{array}{l}\text { Human resource potential of } \\
\text { Māori in modern knowledge, } \\
\text { skills, and competencies }\end{array}$ & $\begin{array}{l}\text { Modern knowledge, skills, and } \\
\text { competencies available to em- } \\
\text { power and enable Māori goals }\end{array}$ & $\begin{array}{l}\text { Modern knowledge, skills, and } \\
\text { competencies available to drive } \\
\text { Māori economic development }\end{array}$ & $\begin{array}{l}\text { Modern knowledge, skills, and } \\
\text { competencies available to fos- } \\
\text { ter social capability }\end{array}$ & $\begin{array}{l}\text { Modern knowledge, skills, and } \\
\text { competencies available to fos- } \\
\text { ter environmental sustainability }\end{array}$ \\
\hline Health & $\begin{array}{l}\text { Cultural and spiritual well- } \\
\text { being are important to health }\end{array}$ & $\begin{array}{l}\text { A person's state of health has } \\
\text { direct impact on their human } \\
\text { resource potential }\end{array}$ & $\begin{array}{l}\text { Empowerment and enablement } \\
\text { of Māori to meet their health } \\
\text { needs }\end{array}$ & $\begin{array}{l}\text { Māori engagement economi- } \\
\text { cally in provision of health ser- } \\
\text { vices and products }\end{array}$ & $\begin{array}{l}\text { Social capability of individuals } \\
\text { and communities used to pro- } \\
\text { vide health care }\end{array}$ & $\begin{array}{l}\text { Failure to maintain environ- } \\
\text { mental sustainability affects } \\
\text { health }\end{array}$ \\
\hline Housing & $\begin{array}{l}\text { Housing is consistent with } \\
\text { principle of traditional building } \\
\text { design in te ao Māori }\end{array}$ & $\begin{array}{l}\text { A person's quality of housing } \\
\text { affects their human resource } \\
\text { potential }\end{array}$ & $\begin{array}{l}\text { Role of Māori in making deci- } \\
\text { sions on housing }\end{array}$ & $\begin{array}{l}\text { Economic value of Māori hous- } \\
\text { ing }\end{array}$ & $\begin{array}{l}\text { Use of Māori housing in build- } \\
\text { ing social capability }\end{array}$ & $\begin{array}{l}\text { Housing that is environmen- } \\
\text { tally sustainable }\end{array}$ \\
\hline $\begin{array}{l}\text { Income and } \\
\text { expenditure }\end{array}$ & $\begin{array}{l}\text { Te ao Māori defines how Māori } \\
\text { get income and spend money }\end{array}$ & $\begin{array}{l}\text { Dynamics of income/ } \\
\text { expenditure and development } \\
\text { of human resource capability }\end{array}$ & $\begin{array}{l}\text { Effect of income on role in } \\
\text { decision-making }\end{array}$ & $\begin{array}{l}\text { Use of income and expenditure } \\
\text { for economic development }\end{array}$ & $\begin{array}{l}\text { Expenditure on building social } \\
\text { capability }\end{array}$ & $\begin{array}{l}\text { Impacts of expenditure on envi- } \\
\text { ronmental sustainability }\end{array}$ \\
\hline Work & $\begin{array}{l}\text { Work is undertaken in main- } \\
\text { taining and developing te ao } \\
\text { Māori concepts }\end{array}$ & $\begin{array}{l}\text { Acquisition of human resource } \\
\text { potential through work }\end{array}$ & $\begin{array}{l}\text { Effect of work status on role in } \\
\text { decision-making }\end{array}$ & $\begin{array}{l}\text { Work as a means of Māori eco- } \\
\text { nomic development }\end{array}$ & $\begin{array}{l}\text { Work as a means of social con- } \\
\text { nection }\end{array}$ & $\begin{array}{l}\text { Work that is environmentally } \\
\text { sustainable }\end{array}$ \\
\hline Social issues & $\begin{array}{l}\text { Strength of te ao Māori in an in- } \\
\text { dividual or community can af- } \\
\text { fect social issues }\end{array}$ & $\begin{array}{l}\text { Human resource potential of an } \\
\text { individual or community can } \\
\text { affect social issues }\end{array}$ & $\begin{array}{l}\text { Impact of social issues in } \\
\text { decision-making }\end{array}$ & $\begin{array}{l}\text { Economic development of an } \\
\text { individual or community can } \\
\text { affect social issues }\end{array}$ & $\begin{array}{l}\text { Impacts of social issues on so- } \\
\text { ciety }\end{array}$ & $\begin{array}{l}\text { Impacts of social issues on en- } \\
\text { vironmental sustainability }\end{array}$ \\
\hline $\begin{array}{l}\text { Māori business } \\
\text { development }\end{array}$ & $\begin{array}{l}\text { Te ao Māori is an intrinsic char- } \\
\text { acteristic of Māori businesses }\end{array}$ & $\begin{array}{l}\text { Impact of human resource ca- } \\
\text { pability on Māori business de- } \\
\text { velopment (and vice versa) }\end{array}$ & $\begin{array}{l}\text { Empowerment of Māori busi- } \\
\text { nesses }\end{array}$ & $\begin{array}{l}\text { Contribution of Māori busi- } \\
\text { nesses to economic self deter- } \\
\text { mination }\end{array}$ & $\begin{array}{l}\text { Contribution of Māori busi- } \\
\text { nesses to building social capa- } \\
\text { bility }\end{array}$ & $\begin{array}{l}\text { Impacts of Māori businesses on } \\
\text { environmental sustainability }\end{array}$ \\
\hline $\begin{array}{l}\text { Participation in polit- } \\
\text { ical decision making }\end{array}$ & $\begin{array}{l}\text { Te ao Māori defines how Māori } \\
\text { view and engage in political de- } \\
\text { cision making }\end{array}$ & $\begin{array}{l}\text { Human resource potential im- } \\
\text { pacts of participation in politi- } \\
\text { cal decision making }\end{array}$ & $\begin{array}{l}\text { Participation in political deci- } \\
\text { sion making empowering and } \\
\text { enabling Māori }\end{array}$ & $\begin{array}{l}\text { Role of participation in polit- } \\
\text { ical decision making in Māori } \\
\text { economic development }\end{array}$ & $\begin{array}{l}\text { Role of participation making } \\
\text { in political decision in building } \\
\text { Māori social capability }\end{array}$ & $\begin{array}{l}\text { Role of participation in politi- } \\
\text { cal decision making in ensuring } \\
\text { environmental sustainability }\end{array}$ \\
\hline Rights & $\begin{array}{l}\text { The Treaty of Waitangi gives } \\
\text { power to aspects of te ao } \\
\text { Māori. Te ao Māori defines } \\
\text { how Māori view their rights }\end{array}$ & $\begin{array}{l}\text { Exercise of rights in developing } \\
\text { human resource potential (and } \\
\text { vice versa) }\end{array}$ & $\begin{array}{l}\text { Exercise of rights in empow- } \\
\text { ering and enabling Māori (and } \\
\text { vice versa) }\end{array}$ & $\begin{array}{l}\text { Exercise of rights in develop- } \\
\text { ing Māori economic develop- } \\
\text { ment (and vice versa) }\end{array}$ & $\begin{array}{l}\text { Exercise of rights in developing } \\
\text { Māori social capability (and } \\
\text { vice versa) }\end{array}$ & $\begin{array}{l}\text { Exercise of rights in ensur- } \\
\text { ing environmental sustainabil- } \\
\text { ity (and vice versa) }\end{array}$ \\
\hline
\end{tabular}

